\title{
Residential Mortgages and Public Policy: What to do with Fannie and Freddie?
}

\author{
David Kohn, PhD, School of Business, University of Bridgeport, Bridgeport, CT and \\ James Sagner, PhD, Sagner/Marks Consulting
}

\begin{abstract}
A.bstragt debate on U.S. housing policy focuses on the role of the government in supporting the mortgage market. Existing organizations (Fannie Mae/Freddie Mac) are in conservatorship, and Congress is considering alternative structures and guarantees including catastrophic insurance in support of the coverage from private companies. This research reviews public policy and the experience of governmental catastrophic insurance with particular reference to FDIC coverage for bank accounts.
\end{abstract}

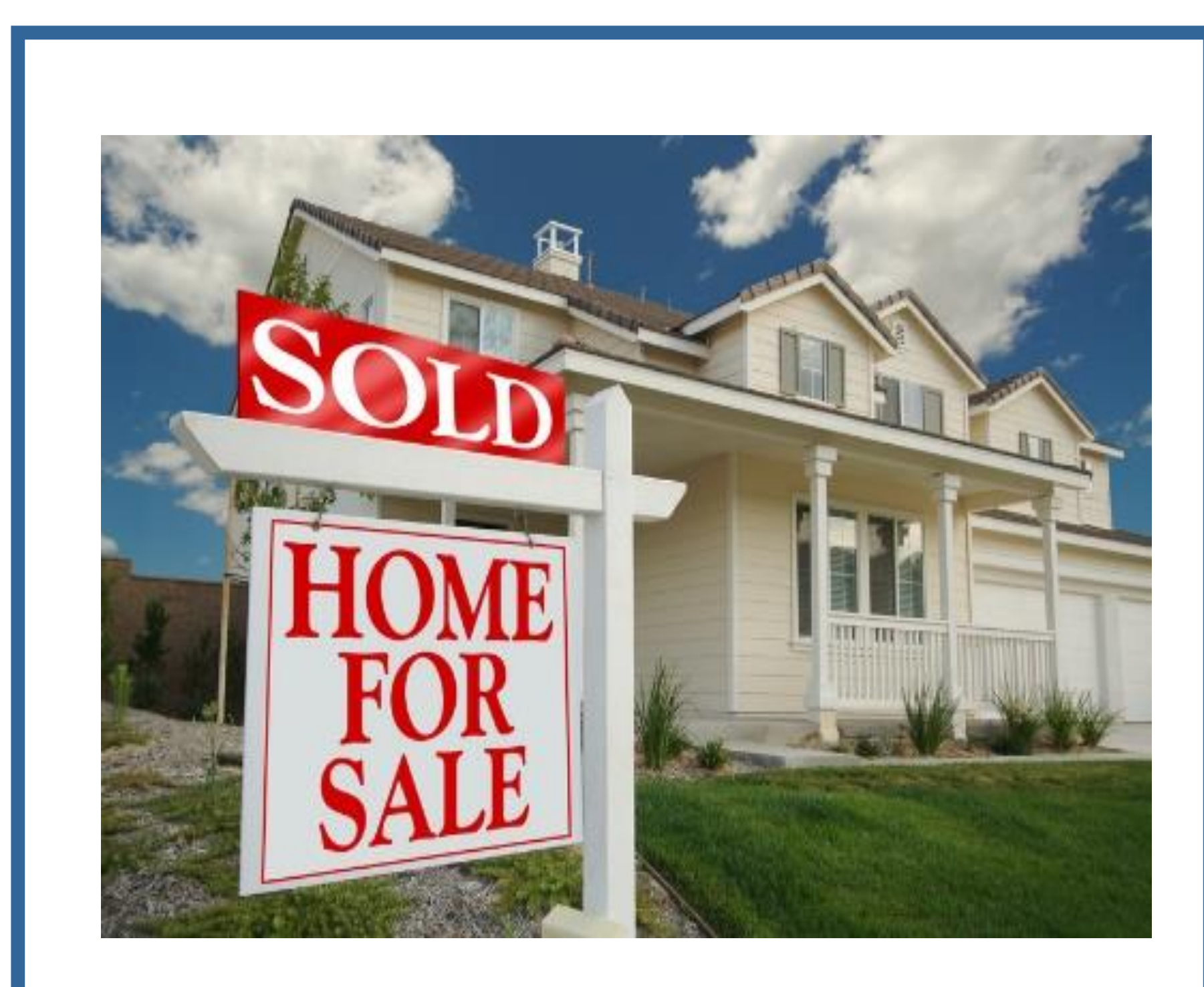

A government-sponsored enterprise (GSE) is a financial services corporation created by the U.S. Congress. Its function is to enhance the flow of credit to targeted sectors of the economy and to make those segments of the capital market more efficient and transparent, and to reduce the risk to investors and other suppliers of capital. The desired effect of the GSEs is to enhance the availability and reduce the cost of credit to the targeted borrowing sectors, primarily by reducing the risk of capital losses to investors in agriculture, home mortgages and education.

The purpose of Fannie Mae (Federal National Mortgage Association) and Freddie Mac (Federal Home Loan Mortgage Corporation) has been to support the secondary mortgage market by securitizing mortgages in the form of mortgage-backed securities (MBS). This allows lenders to reinvest their assets into more lending and in effect increase the number of lenders in the mortgage market. The Federal Housing Finance Agency, supported by the U.S. Treasury, placed Fannie/Freddie into conservatorship in September 2008. It was one of the significant financial events among many in the ongoing subprime mortgage crisis.
Congress passed the Dodd-Frank Wall Street Reform and Consumer Protection Act in 2010 creating the Financial Stability Oversight Council with the power to designate Systemically Important Financial Institutions (SIFIs). The law defines these financial institutions whose failure might trigger a financial crisis that would endanger the financial system. All U.S. bank holding companies with assets exceeding $\$ 50$ billion are automatically SIFIs; the FSOC can designate others, even if they are not banks. Dodd-Frank identifies many considerations, including: financial leverage, both on and off the formal balance sheet; interconnectedness with other SIFIs; the importance of a company as a source of credit for households, businesses and local governments; and maturity (duration) mismatches between short-term funding and long-term lending. (Financial leverage is using debt to increase the assets of an organization's balance sheet.)

Fannie Mae and Freddie Mac helped put the U.S. into its biggest bad debt and banking crisis since 1933, with their guarantees of securities backed by mortgage loans. The GSE's could not pursue prudent lending once the government decided to pursue an explicit policy of home ownership for "sub-prime" borrowers, who would not be qualified for conventional loans based on traditional banking standards. Subprime loans tripled (as a percentage of all housing credit) between 2001 and 2006, with down payments permitted as low as $3 \%$ of loanto-(appraised house) value. The financial collapse that began in 2008 led to massive loan defaults by these borrowers, many situations where the mortgage amount exceeded the value of the home, and the cessation of required monthly mortgage payments of principal and interest. The two firms received a $\$ 187$ billion federal bailout and have been required to transfer all of their profits to the U.S. Treasury.

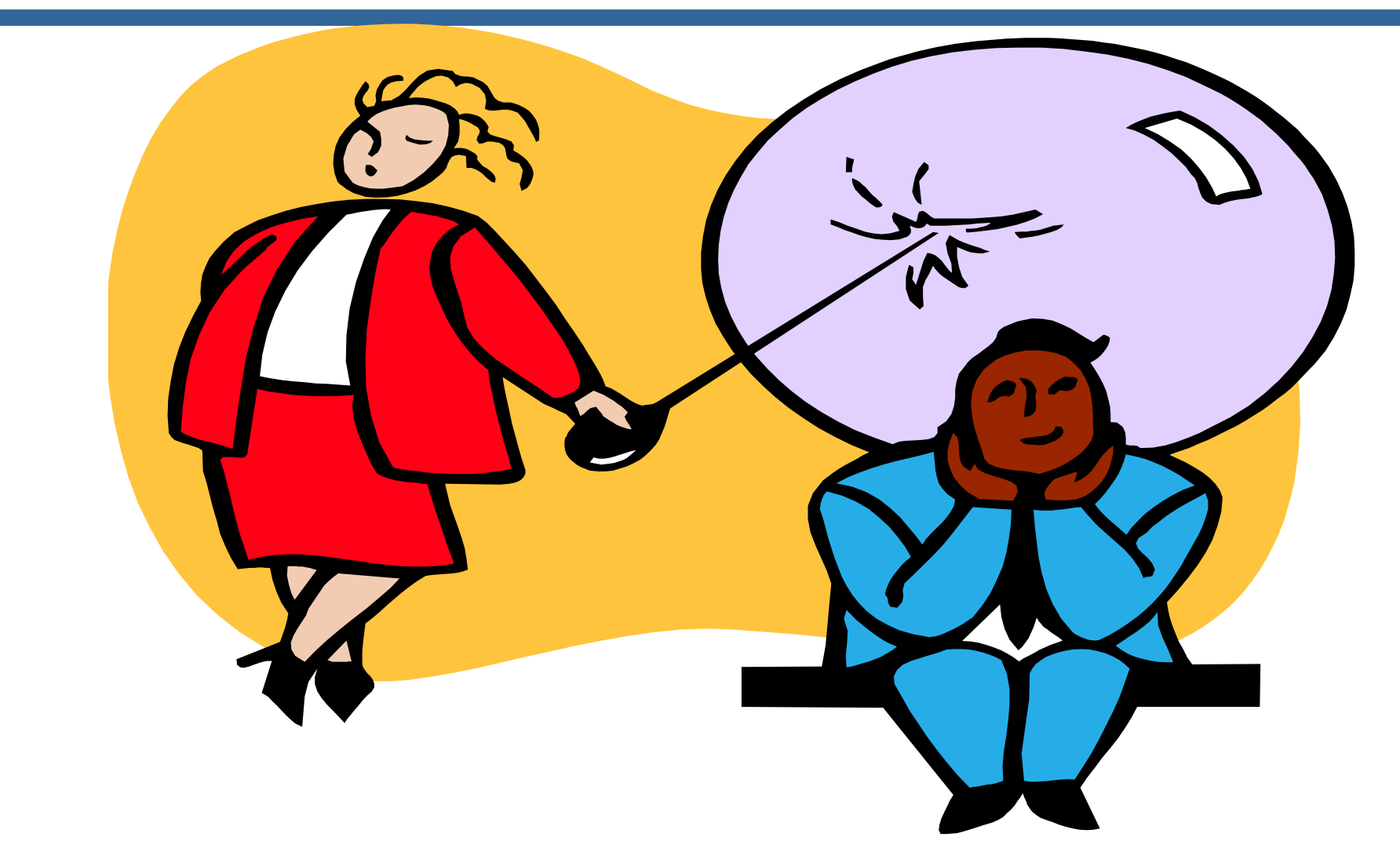

Although not so designated, Fannie/Freddie are each bigger than the largest financial institutions which have made the SIFI list. With $\$ 3.3$ trillion in assets, Fannie would in fact be the biggest SIFI in the U.S. and in the world, and Freddie would be in fourth place in the U.S. More importantly, Fannie is leveraged 341-to-1 and Freddie has leverage of 153-to-1.
Although they currently are profitable, paying dividends to the Treasury, Fannie/ Freddie would not exist today without government assistance, and are leading examples of "too big to fail". Support continues due to a lack of consensus on how to replace them without a complete and painful overhaul of the U.S. housingfinance system. Who was to blame? In retrospect there were many "smoking guns" responsible for this situation (Note: MBS = mortgage-backed securities)

- Lenders (for sub-prime mortgages)

- Investment bankers (for writing MBSs)

- Rating agencies (for incorrect assigned investment grade ratings)

- Institutional investors (for purchasing MBSs without any real analysis)

- Regulators (for insufficient oversight)

- Congress (for insisting on home ownership for lower income groups)

Is there a solution? In 2015-2016, the

Senate may reconsider the Housing Finance Reform and Taxpayer Protection Act of 2014 (also known as the Johnson-Crapo Bill for its Senate sponsors), which effectively ends Fannie/Freddie, provides catastrophic insurance relief for private lenders and mortgage insurers who would be required to retain a percentage of (and not securitize) those loans and would suffer losses to the point where a federal loan guarantee would provide relief. This concept would force lenders to retain some ownership of mortgage loans, thereby assuring more prudent lending. What are the criticisms of Johnson-Crapo? The bill features a controversial, possible politicization of mortgage credit for affordable housing. Some Democrats on the Senate Banking Committee said the bill would make the cost of a mortgage go up too much for middle-income borrowers, does not do enough to fund affordable housing in low-income neighborhoods, and amounts to too significant of an overhaul of the system when changes to the current model may be the best approach.

The Research. The role of the Federal Deposit Insurance Corp. (FDIC) in a catastrophic event (a bank failure) will be compared to a proposed program of catastrophic mortgage insurance. In a bank failure, the FDIC seizes the bank's assets, reorganizes or closes the bank, and pays off depositors. Mortgage insurance could function in an equivalent manner, varying premiums based on the riskiness of the mortgages covered by private insurers based on FICO scores and loan-to-value proportions. Successes/failures from FDIC experience, particularly since the 2008 Great Recession, will be reviewed. 